\title{
EVALUATION METHODS OF IMAGE SEGMENTATION QUALITY
}

Context. The basic methods of quantitative evaluation of image segmentation quality are explored. They are used to select segmentation algorithms for specific image classes. The object of the study is cytological and histological images that are used in diagnosing the pathological processes in oncology. The subject of the study is quantitative methods for segmentation algorithms' quality evaluation.

Objective. The purpose of the work is to introduce the Gromov-Fr échet metric and develop a metric-based method for quantitative evaluation of segmentation quality for image segmentation algorithms' comparison.

Method. The quantitative evaluation criteria, which are based on comparison with etalon image and without the comparison with etalon image, are analyzed. The algorithms for measuring the distances between images based on the Fre chet, Hausdorff, and Gromov-Hausdorff metrics are analyzed.

To calculate the distance between the contours of images, the Gromov-Fréchet distance was introduced. The condition of identity, symmetry and triangle is proved, and it is shown that the Gromov-Fr échet distance is a metric.

The metric-based method of quantitative evaluation of segmentation quality is developed. It is based on the use of the Gromov-Hausdorff and Gromov-Fr échet metrics. The method is based on the algorithms for non-convex-into-convex polygon transformation, weighted chord algorithm, and algorithms for calculating the Fréchet and Hausdorff distances. To calculate the Hausdorff distance between convex regions, the Atalah's algorithm was used. The Thierry and Manillo algorithm was used to find the discrete Fréchet distance. These algorithms have the lowest computational complexity among their class of algorithms.

Results. The Gromov-Fr échet metric was introduced and the metric-based method of quantitative evaluation of segmentation quality was developed.

Conclusions. The conducted experiments on the basis of cytological images confirmed the performance of software for evaluation the distances between images. The developed method showed a high accuracy of estimation the distances between images. The developed software module was used in intelligence systems for diagnosing the breast precancerous and cancerous conditions. The software can be used in various software systems of computer vision. Promising areas for further research are search for new metrics to evaluate the distances between images.

Keywords: segmentation, quantitative segmentation evaluation, Fréchet metric, Hausdorff metric, Gromov-Hausdorff metric, GromovFr chet metric, polygon, cytological images.

\section{NOMENCLATURE}

AMS - automated microscopy system;

$\mathrm{AR}$ - area relation;

FOM - figure of merit;

NR FOM - number relation figure of merit;

AUMA - absolute ultimate measurement accuracy;

RUMA - relative ultimate measurement accuracy;

FOC - figure of certainty;

FRAG- fragmentation;

CSP - correctly selected pixels;

PDE - pixel distance error;

$I$ - a predefined image;

$I^{e}-$ an expert (etalon) image;

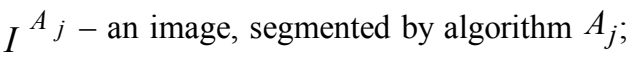

$A_{j}$ - a segmentation algorithm;

$d\left(I^{e}, I^{A j}\right)=d_{j}-$ a distance between etalon image $I^{e}$

and segmented image $I^{A_{1}}$ by algorithm $A_{j}$;

$d(x, y)$ - an Euclidean distance between points $x$ and $y$;

$d_{H}-$ a Hausdorff distance;

$d_{2}\left(V_{2}, W_{2}\right)-$ a distance between contours;

$d_{F}-$ a Frŭchet distance;

$d_{G H}$ - a Gromov-Hausdorff distance;

$d_{G F}$ - a Gromov-Fr échet distance;

$A, B$ - compact sets; $f, g$ - continuous curves;

$\alpha, \beta$ - arbitrary continuous non-decreasing function;

$(X, d)$ - metric space $X$ with metric $d$;

$\gamma_{i}$ - parameterized curves in metric spaces,

$f, g$ - isometric embeddings into a space;

$Z$ - a set of isometric transformations;

$P, Q, P_{i}, Q_{j}$ - polygons;

$C_{P_{i}}$ - a contour (external boundary) of convex polygon $P_{i}$

$O_{P_{i}}-$ an internal boundary of convex polygon $P_{i}$;

$d_{1}\left(V_{1}, W_{1}\right)$ - a distance between regions;

$D$ - a combined distance;

$\varphi, \lambda$ - weighted coefficients;

$V$ - initial set of polygon vertices;

$n$ - a number of vertices in polygon;

$m-$ a number of vertices corresponding to condition $\alpha_{i}<180^{\circ}$;

$B$ - a set of polygon vertices after convex regions formation;

$\alpha_{i}-$ interior angles of the polygon;

$O$ - algorithm computational complexity.

\section{INTRODUCTION}

Image processing and analysis have been widely used in computed tomography, magnetic resonance tomography, 
$X$-ray imaging (digital radiography), histology and cytology, etc. [1]. For diagnostics in oncology, automated microscopic system (AMS) are used to process and analyze cytological and histological images.

The object of this research is cytological and histological image segmentation.

Cytological image is a microscopic image of preparations containing cells and their components (nucleus, cytoplasm) [2]. Histological image is a microscopic image of preparation thin sections of fixed tissues that reflect their structure [3].

The main disadvantages of most histological and cytological images are low quality, non-uniform illumination of areas, presence of noise, lack of clear contours between the microscopic objects and the background. It is known that image segmentation is crucial for the average computer vision. There are many algorithms for image segmentation, such as threshold, watershed distribution, $k$-means, and others. Therefore, the choice of segmentation algorithms and their parameters is of great significance. To select the optimal parameters for segmentation algorithms, it is necessary to evaluate the results of segmentation.

The subject of the research is methods of segmentation quality evaluation.

There are the following segmentation evaluation criteria: non-standard segmentation criteria that do not require standard (etalon) segmentation and standard (etalon-based) segmentation criteria.

One of the main criteria of the first group is homogeneity of segments. This approach is based on calculation of value dispersion of a certain image feature used for segmentation [4]. Another criterion for evaluating segmentation is contrast between segments. Besides, a shape of a segment is also a criterion that can help evaluate segmentation quality. This criterion can be effectively used for a specific image analysis. The advantage of using non-standard criteria is simplicity and speed.

The most famous algorithms belonging to the second group are AR, FOM, NR FOM, AUMA, RUMA, FOC, Baddeley, Average Distance, Variance distance, FRAG [5]. This group of algorithms is based on the use of metrics [6]. The results of etalon-based segmentation are compared with the results of specific segmentation algorithm. The main advantage of the second group of algorithms is high accuracy of evaluation.

There is no single unified theory of image segmentation. Most algorithms are heuristic in nature. Therefore, the actual problem is objective quantitative evaluation of segmentation quality.

The purpose of this article is to analyze and compare the current evaluation methods of image segmentation, develop a metric-based method and algorithms for quantitative evaluation of image segmentation using histological and cytological images.

\section{PROBLEM STATEMENT}

Let $I$ be a predefined image (fig. 1). Expert (etalon) image $I^{e}$ is obtained after expert's segmentation. Let image $I^{A_{j}}$ be an image segmented by algorithm $A_{j}$. Then the distance

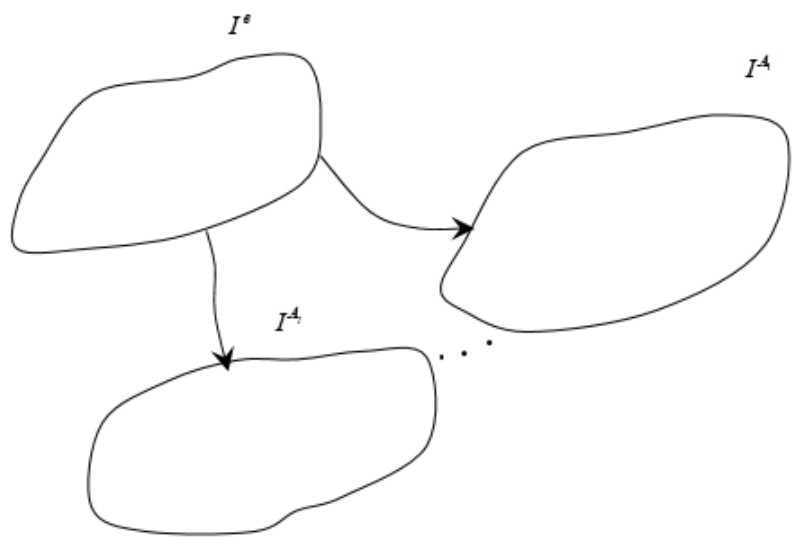

Figure 1 - Expert image and image segmented by algorithms

between an etalon image and an image segmented by algorithms $A_{i}$ will be equal to $d\left(I^{e}, I^{A_{i}}\right), i=1, \ldots, l$.

It necessary to find out the algorithm $A_{j}$ that meets the requirement of distance minimum $d_{j}=\min \left(d_{1}, d_{2}, \ldots, d_{l}\right)$.

It is necessary to find out the algorithm.

\section{LITERATURE REVIEW}

Segmentation quality evaluation has become a research focus of many researchers since the late $80 \mathrm{~s}$ - early $90 \mathrm{~s}$. Zhang, Mattana, and Huo [5] stated that it is accuracy of individual objects' selection that can serve as image segmentation evaluation. The authors considered individual characteristics of objects. To evaluate the threshold segmentation methods, Lee, Chung, and Park introduced segmentation error probability criterion based on counting wrongly classified pixels. Yasnoff and Mui [7] introduced pixel distance error (PDE) to find out the distances between pixels in the target and segmented images. The longer the distance is, the higher the segmentation error will be. Gerbrands [8] introduced FOM criterion to determine the distance between the segmented pixel and "correct" pixel location. Criterion RUMA, offered by Zhang [9], uses geometric object parameters to evaluate segmentation quality.

The analyzed criteria mainly evaluate the distances between individual objects in etalon and segmented images. In practice, it is necessary to evaluate the quality of segmentation for a group of objects.

The algorithms for comparing segmentation results by means of metrics are based on known Frŭchet and Hasdorf metrics.

Thus, Lopez and Reisner [10] developed an algorithm to reduce a number of vertices of the convex polygon for a given error $\xi$ in the Hausdorff metric. The algorithm can be used only for convex polygons. Alt and Scharfz [11] calculated the Hausdorff distance between algebraic plane curves using Voronoi diagrams. The algorithm is used for partial cases with algebraic curves and has a high computational complexity. Chew and Kedem [12] developed an algorithm for finding the minimum Hausdorff distance in metrics $L_{i}$ and $L_{\infty}$. The resulting computational complexity 
is $O\left(n^{2} \cdot \log ^{2} n\right)$. Knauer and Scherfenberg [13] developed a search method by a given image pattern, which has the least distance in the metric of Hausdorff. In this case, translation of the specified pattern is used to the search image. The algorithm has a high computational complexity. Alvarez and Seidel [14] developed a method for finding the minimum weight spanning tree based on the Hausdorff metric for $d$-dimensional space. The problem of approximation of such a tree is solved in polynomial time. Atallah [15] developed an algorithm for finding the Hausdorff distance between convex polygons. The computational complexity of this algorithm is $O(m \cdot n)$, where $m$ and $n$ refer to a number of vertices of the first and second polygons, respectively.

A number of publications are devoted to the development of algorithms for finding the Frŭchet distance between curves. Alt and Godau [16] developed algorithms for finding the distance between parametric curves. The computational complexity is $O(m n \cdot \log m n)$. Mosig and Clausen [17] developed an algorithm for calculating the Frŭchet discrete distance for polygonal curves. They used groups of rigid motion. The computational complexity is $O\left(m^{2} \cdot n^{2}\right)$, where $m$ and $n$ refer to a number of fragments on the first and second curves. K. Buchin, M. Buchin, and Wenk [18] developed an algorithm for calculating the Frŭchet distance for surfaces that are represented by simple polygons. The algorithm has a polynomial complexity. Rote [19] developed the algorithm for calculating the Frŭchet distance between two curves given by the set of $m$ and linearly approximated segments. The computational complexity is $O(m \cdot n)$. Schlesinger, Vodolazskiy, and Yakovenko [20] obtained the computational complexity $O(m \cdot n)$ for the Frŭchet metric for closed polygonal curves. Ahn et al [21] developed an algorithm for calculating the Frŭchet distance with inaccurately given vertices. For $d$-dimensional space they obtained the computational complexity of $O(d \cdot m \cdot n)$. Cook, Driemel, Sherette, and Wenk [22] developed an algorithm for calculating the Frŭchet distance between non-flat surfaces. The authors reached the polynomial time in the $L_{\infty}$ metric. Gudmundsson and Smid [23] developed a fast algorithm for finding the similarity of polygonal trees in the Frŭchet metric. The algorithm has a polynomial complexity.

Eiter and Mannila [24] developed an algorithm for finding the Frŭchet discrete distance between polygons. The computational complexity of the algorithm is $O(m \cdot n)$. The best algorithms for finding the Frŭchet distance for plane closed curves have the computational complexity of $O(m \cdot n)$. The best algorithms for finding the Hausdorff distance for convex regions have computational complexity $O(m \cdot n)$.

The mentioned algorithms calculate the distances separately between the curves (contours) of the images in the Fréchet metric and between the regions of the images in the Hausdorff metric.
Therefore, it is necessary to develop a metric, method, and software for evaluating segmentation quality for complex images with many objects.

\section{MATERIALS AND METHOD}

In order to compute distances between images, we use Hausdorff and Frŭchet metrics. To compute the shortest distances between images, we use Gromov-Hausdorff and Gromov-Fr échet metrics.

We present the basic metrics below.

Frŭchet metric. Let $X$ be a metric space with a metric $d$. For two curves $f:[a, b] \rightarrow X$ and $g:\left[a^{\prime}, b^{\prime}\right] \rightarrow X$, the Frŭchet distance between them is equal to [10]:

$$
d_{F}=\inf _{\alpha, \beta} \sup _{t \in[0,1]} d(f(\alpha(t)), g(\beta(t))),
$$

where $\alpha$ and $\beta$ are arbitrary non-decreasing continuous functions from the interval $[0,1]$ on intervals $[a, b]$ and $\left[a^{\prime}, b^{\prime}\right]$, respectively. The value of function is $\alpha(0)=0$ and $\alpha(1)=1$, and it is similar for function $\beta$.

Hausdorff metric. For a metric space $(X, d)$, the Hausdorff metric $d_{H}$ will be called a metric on the set $\mathfrak{I}$ of all non-empty compact subsets $X$, which is defined by means of the formula [25]:

$$
d_{H}^{X}(A, B):=\max \left\{\max _{x \in A} \min _{y \in B} d(x, y), \max _{y \in B} \min _{x \in A} d(x, y)\right\} .
$$

Gromov-Hausdorff metric. The distance between two compact sets $A$ and $B$ is equal to [26]:

$$
d_{G H}(A, B):=\inf _{X, f, g} d_{H}^{X}(f(A), g(B)),
$$

where $f: A \rightarrow X, \quad g: B \rightarrow X$ denote isometric embeddings into a metric space $(X, d)$.

Gromov-Fréchet metric. To measure the distance between two curves, we use Gromov-Fr échet metric:

$$
d_{G F}(S, Q):=\inf _{X, S, Q} d_{F}^{X}(f(S), g(Q)),
$$

where $f: S \rightarrow X, g: Q \rightarrow X-$ isometric embeddings into a metric space $(X, d)$. Suppose there are two parameterized curves in metric spaces $\gamma_{i}:[0,1] \rightarrow X_{i}, i=1,2 .\left(X_{i}, d_{i}\right)$ is a metric, $t \rightarrow \gamma_{i}(t) \in X_{i}$ (fig. 2). We embed isometrically $j_{i}: X_{i} \rightarrow Z, i=1,2,(Z, d)$.

Then we take a Fré chet distance between $j_{1} \gamma_{1}$ and $j_{2} \gamma_{2}$,

$$
d_{F}\left(j_{1} \gamma_{1}, j_{2} \gamma_{2}\right)
$$

Finally, infimum of such (1) along all isometric embeddings $j_{1}, j_{2}$ will be a Gromov-Fréchet distance:

$$
d_{G F}\left(\gamma_{1}, \gamma_{2}\right)=\inf _{j_{1}, j_{2}, Z} d_{F}\left(j_{1} \gamma_{1}, j_{2} \gamma_{2}\right) .
$$




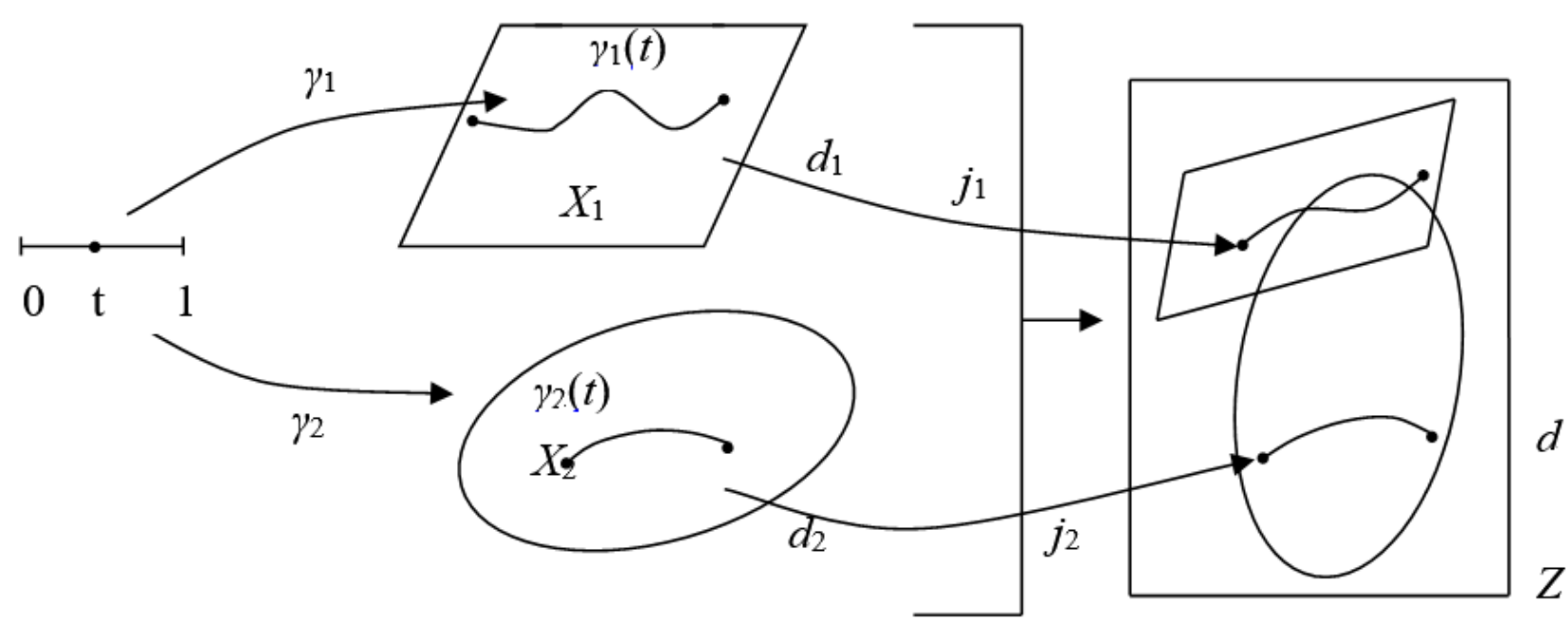

Figure 2 - Gromov-Fréchet metric between two parameterized curves

Theorem. The function $d_{G F}$ is a metric.

Proof. First we check if the definition is correct. Having two spaces $X_{1}$ and $X_{2}$ we consider their bouquet $Z=X_{1} \vee X_{2}$, sticking together two arbitrary points $x_{1}^{0}$ and $x_{2}^{0}$.

Let us define a metric $d$ in a bouquet by means of the formula:

$$
d(x, y)=\left\{\begin{array}{l}
d_{i}(x, y), \text { if } x, y \in X_{i} . \\
d_{1}\left(x, x_{1}^{0}\right)+d_{2}\left(x_{2}^{0}, y\right), \text { if } x \in X_{1}, y \in X_{2} .
\end{array}\right.
$$

Then we check the definition of a metric for $d_{G F}$.

Obviously, $d_{G F}\left(\gamma_{1}, \gamma_{2}\right) \geq 0$.

Besides, $d_{G F}(\gamma, \gamma)=0$ for each $\gamma$.

Let us denote that the definition implies that $d_{G F}\left(\gamma_{1}, \gamma_{2}\right) \geq d_{G F}\left(\gamma_{1}([0,1]), \gamma_{2}([0,1])\right)$.

If $d_{G F}\left(\gamma_{1}, \gamma_{2}\right)=0$, then it implies that $d_{G F}\left(\gamma_{1}([0,1]), \gamma_{2}([0,1])\right)=0$, therefore, we can assume that $\gamma_{1}([0,1])=\gamma_{2}([0,1])$.

The last equality in case of embedded curves gives equality $\gamma_{1}=\gamma_{2}$ exactly to parameterization. The symmetry of function $d_{G F}$ is obvious.

Let us verify the triangle inequality. Let $\gamma_{i}:[0,1] \rightarrow X_{i}$, $i=1,2,3$ be parameterized curves; $d_{G F}\left(\gamma_{1}, \gamma_{2}\right)=a$, $d_{G F}\left(\gamma_{2}, \gamma_{3}\right)=b$; and $\varepsilon>0$. There are metric spaces $Z_{12}$ and $Z_{23}$, and such isometric embeddings

$$
\begin{gathered}
j_{i}: X_{i} \rightarrow Z_{12}, i=1,2, \\
k_{i}: X_{i} \rightarrow Z_{23}, i=2,3,
\end{gathered}
$$

so that

$$
\begin{aligned}
& d_{F}\left(j_{1} \gamma_{1}, j_{2} \gamma_{2}\right)<a+\varepsilon, \\
& d_{F}\left(k_{2} \gamma_{2}, k_{3} \gamma_{3}\right)<b+\varepsilon .
\end{aligned}
$$

Let $Z=Z_{12} \cup_{k_{2} j_{2}^{-1}} Z_{23}$. In other words, $Z$ is derived from $Z_{12} \cup Z_{23}$ by identification of each point $j_{2}(x)$ with point $k_{2}(x), x \in X_{2}$.

Metric $d$ on $Z$ is defined by the formula:

$$
d(x, y)=\left\{\begin{array}{l}
d^{\prime}(x, y), \text { if } x, y \in Z_{12} . \\
d^{\prime \prime}(x, y), \text { if } x, y \in Z_{23} . \\
\inf \left\{d^{\prime}\left(x, j_{2}(z)\right)+d^{\prime \prime}\left(k_{2}(z), y\right) \mid z \in X_{2}\right\}, \text { if } x \in Z_{12}, y \in Z_{23} .
\end{array}\right.
$$

(Here $d^{\prime}$ is a metric on $Z_{12}, d^{\prime \prime}$ is a metric on $Z_{23}$ ).

Then from the triangle inequality for $d_{F}$ it derives that

$d_{G F}\left(\gamma_{1}, \gamma_{2}\right) \leq d_{F}\left(j_{1} \gamma_{1}, k_{3} \gamma_{3}\right) \leq d_{F}\left(j_{1} \gamma_{1}, j_{2} \gamma_{2}\right)+$

$+d_{F}\left(k_{2} \gamma_{2}, k_{3} \gamma_{3}\right)<a+b+2 \varepsilon=$

$=d_{G F}\left(\gamma_{1}, \gamma_{2}\right)+d_{G F}\left(\gamma_{2}, \gamma_{3}\right)+2 \varepsilon$

Since $\varepsilon>0$ is arbitrary, we obtain the required inequality.

To evaluate segmentation quality, the researchers developed quantitative evaluation method of segmentation quality (QEMSQ), which is built on metric-based measuring the distance between images.

After segmentation, we obtain a set of segments that we approximate linearly and get a set of polygons. In general, they are not convex. Thus, the task is to compare two nonconvex polygons after a specific algorithm segmentation and expert segmentation.

Let $P$ and $Q$ be two non-convex polygons (fig. 3). 

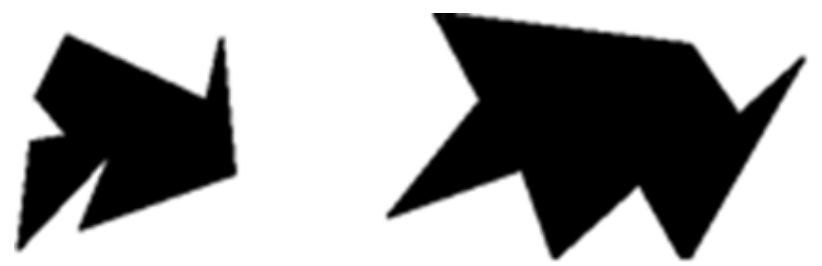

Figure 3 - Polygons $P$ and $Q$

Let us divide polygons $P$ and $Q$ into sets of convex polygons, that is, $P=P_{1} \cup \ldots \cup P_{i} \cup \ldots \cup P_{n}$, $Q=Q_{1} \cup \ldots \cup Q_{j} \cup \ldots \cup Q_{m}$. Each convex polygon $P_{i}$ and $Q_{j}$ is represented as $P_{i}=C_{P_{i}} \cup O_{P_{i}}$, where $C_{P_{i}}$ and $O_{P_{i}}$ are contour (external boundary) and internal region of convex polygon $P_{i}$, respectively. Similarly, polygon $Q: Q_{j}=C_{Q_{j}} \cup O_{Q_{j}}$.

Then we receive

$$
\begin{aligned}
& \left.P=\left(C_{P_{1}} \cup O_{P_{1}}\right) \cup\left(C_{P_{i}} \cup O_{P_{i}}\right) \cup \ldots \cup\left(C_{P_{n}} \cup O_{P_{n}}\right)\right\} \mid V, \\
& \left.Q=\left(C_{Q_{1}} \cup O_{Q_{1}}\right) \cup\left(C_{Q_{j i}} \cup O_{Q_{j i}}\right) \cup \ldots \cup\left(C_{Q_{m}} \cup O_{Q_{m}}\right)\right\} \mid W .
\end{aligned}
$$
form:

Let us represent the latter expressions in the following

$$
\begin{aligned}
& P=\left(C_{P_{1}} \cup \ldots \cup C_{P_{i}} \cup \ldots \cup C_{P_{n}}\right) \cup\left(O_{P_{1}} \cup \ldots \cup O_{P_{i}} \cup \ldots \cup O_{P_{n}}\right), \\
& Q=\left(C_{Q_{1}} \cup \ldots \cup C_{Q_{j}} \cup \ldots \cup C_{Q_{m}}\right) \cup\left(O_{Q_{1}} \cup \ldots \cup O_{Q_{j}} \cup \ldots \cup O_{Q_{m}}\right) .
\end{aligned}
$$

Denote:

$$
\begin{aligned}
& C_{P_{1}} \cup \ldots \cup C_{P_{i}} \cup \ldots \cup C_{P_{n}}=V_{1}, \\
& O_{P_{1}} \cup \ldots \cup O_{P_{i}} \cup \ldots \cup O_{P_{n}}=V_{2}, \\
& C_{Q_{1}} \cup \ldots \cup C_{Q_{j}} \cup \ldots \cup C_{Q_{m}}=W_{1}, \\
& O_{Q_{1}} \cup \ldots \cup O_{Q_{j}} \cup \ldots \cup O_{Q_{m}}=W_{2} .
\end{aligned}
$$

Then the distance between polygons $P$ and $Q$ is equal to a sum of distances between contours and internal regions of convex polygons $P_{i}$ and $Q_{j}$. The distance between regions equals:

$$
d_{1}\left(V_{1}, W_{1}\right)=\inf \left\{\varepsilon_{1}>0 \mid \forall i=\overline{1, n}, \exists j=\overline{1, m}, d_{H}\left(O_{i}, O_{j}\right) \leq \varepsilon_{1}\right.
$$
and vice versa $\forall j=\overline{1, m}, \exists i=\overline{1, n}$, and $\left.d_{H}\left(O_{i}, O_{j}\right) \leq \varepsilon_{1}\right\}$, $d_{H}-$ a Hausdorff distance.

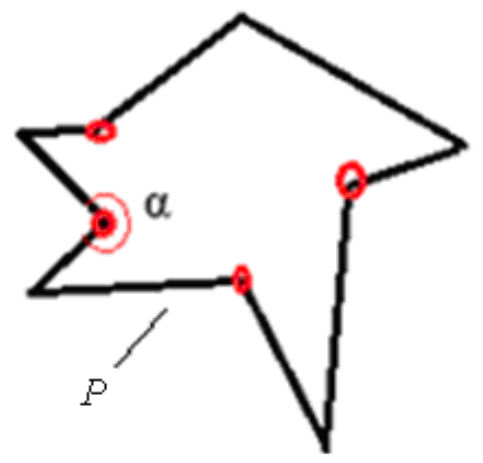

a
Similarly, we calculate the distances between contours: $d_{2}\left(V_{2}, W_{2}\right)=\inf \left\{\varepsilon_{2}>0 \mid \forall i=\overline{1, n}, \exists j=\overline{1, m}, d_{F}\left(C_{i}, C_{j}\right) \leq \varepsilon_{2}\right.$ and vice versa $\forall j=\overline{1, m}, \exists i=\overline{1, n}$, and $\left.d_{F}\left(C_{i}, C_{j}\right) \leq \varepsilon_{2}\right\}$, $d_{F}-$ a Fr chet distance.

Quantitative evaluation method of segmentation quality is based on a combination of algorithms that ensure finding the shortest distances between images. This combination includes a set of algorithms: algorithm for non-convex-intoconvex polygon transformation, weighted chords algorithm, Hausdorff distance algorithm, and discrete Fréchet distance algorithm.

Stepwise quantitative evaluation method of segmentation quality can be represented as follows:

1. Formation of a convex polygons' set.

2. Conducting isometric transformations for embedding convex polygons with a maximum cross section.

3. Computing a Fréchet distance for convex polygons.

4. Computing a Hausdorff distance for convex polygons.

5. Finding the shortest distance based on weighted metrics (Fréchet and Hausdorff metrics) between polygons $P$ and $Q$ according to $D=\varphi d_{H}+\lambda d_{F}$.

Let us describe the basic algorithms that underpin this method.

Algorithm for non-convex-into-convex polygon transformation:

Let $P$ be a non-convex polygon with vertices $V=\left\{v_{0}, v_{1}, \ldots, v_{n-1}\right\}$. Algorithm for convex polygon formation consists of the following steps:

1. Beginning with an upper vertex, we select the vertices with internal angles $\alpha_{i}$ larger than $180^{\circ}$. If such angles do not exist, then the polygon is convex and the algorithm is completed. Otherwise, we get an array of vertices $B=\left\{b_{0}, b_{1}, \ldots, b_{m}\right\}$.

2. We connect consistently the received vertices $b_{1}$ beginning with the top vertex and get a polygon $P_{1}$.

3. We repeat step 1 with a received polygon $P_{1}$.

4. We repeat steps 1 and 2 with polygons $P_{1}$ until the angle of each vertex meets the condition $\alpha<180^{\circ}$.

The algorithm is graphically demonstrated in fig. 4

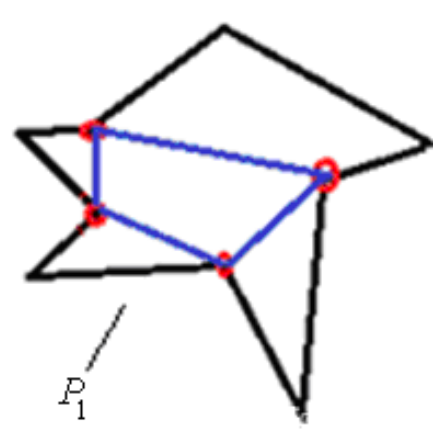

b

Figure 4 - Partitioning non-convex polygon into convex polygons: a - polygon $P$, with internal angles larger than $180^{\circ}, \mathrm{b}-$ polygon $P_{1}$, convex region formation 
Algorithm computational complexity is $O(n+m)$, where $n$ is a number of vertices of initial non-convex polygon and $m$ is a number of vertices of non-convex polygon.

Weighted chords algorithm is described in the article of Berezsky, Melnyk, Batko, and Pitsun [27] Computational complexity of the algorithm is $O(n \cdot m)$, where $n$ is a number of weighted chords of the first polygon and $m$ is a number of weighted chords of the second polygon. For convex regions' comparison, the Atallah's algorithm [15] was used. For contour comparison, we used the Fréchet discrete distance algorithm developed by Eiter and Mannila [25]. So, the developed QEMSQ algorithms have the least computational complexity.

\section{EXPERIMENTS}

For computer experiments, we used cytological images [28].

To compare segmentation quality of individual micro objects, we use etalon image shown in fig. 5 .

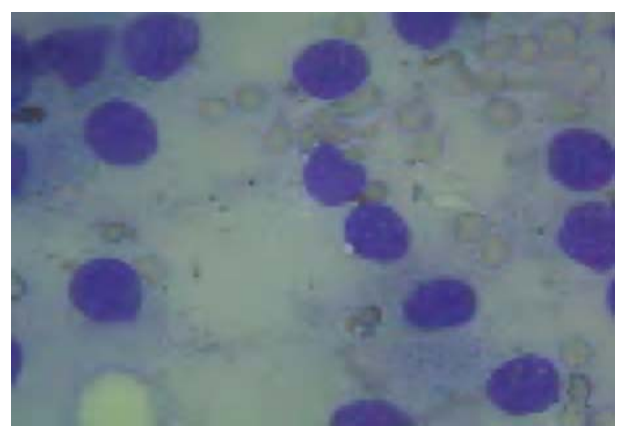

a
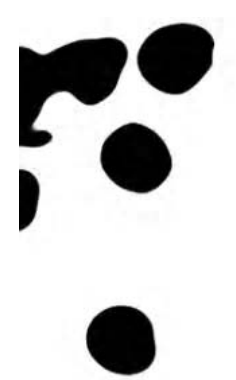

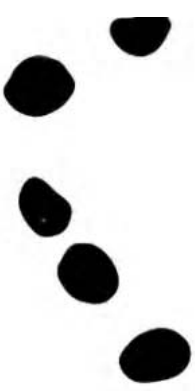

Other images for these experiments were generated randomly. In this case, we use the following methods to evaluate segmentation quality: CSP, WSP, PDE, FRAG, AUMA, and RUMA.

To evaluate segmentation quality of micro objects' groups, we use cytological images. Fig. 6 shows the etalon image and images segmented by means of thresholding, $k$-means, and watershed distribution algorithms [29]. We used Hausdorff, Fré chet, Gromov-Hausdorff, and Gromov-Fr échet metrics.

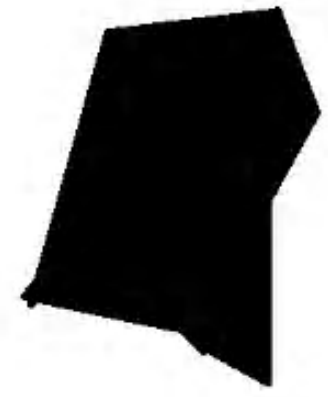

Figure 5 - Etalon image
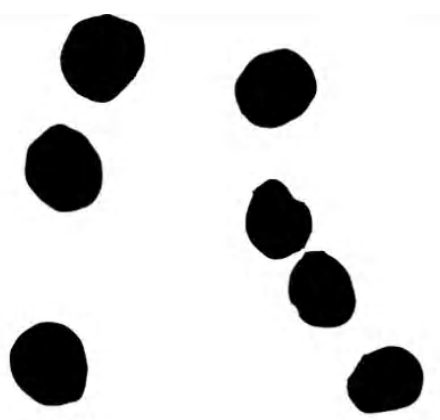

b
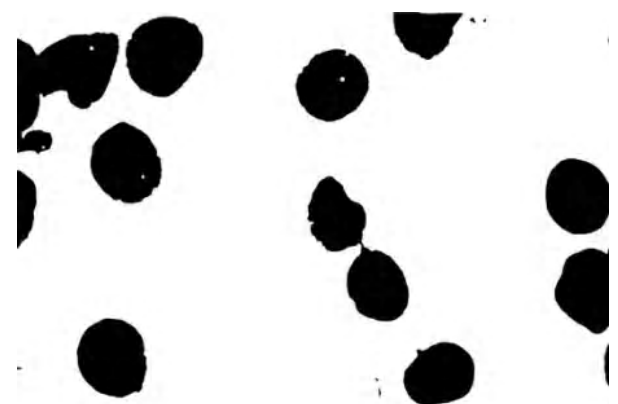

d

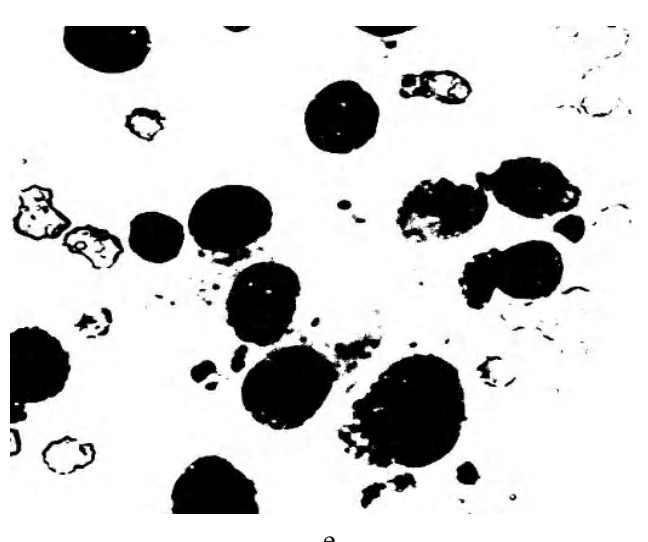

Figure 6 - Image segmentation: a - output image, $\mathrm{b}$ - etalon image, $\mathrm{c}$ - segmentation results by k-means + threshold algorithms, $\mathrm{d}-$ segmentation results by watershed + threshold algorithms, e - segmentation results by threshold algorithm 


\section{RESULTS}

Comparative analysis of image segmentation is demonstrated in Table 1.

Thus, the described methods of segmentation quality evaluation rated the most similar to etalon images and the most dissimilar images. These methods should be used to evaluate the segmentation quality of individual microscopic objects rather than the entire image as a whole. Table 2 shows the results of segmentation quality evaluation of images illustrated in fig. 6 .

Analysis of data in Table 2 demonstrates that GromovFré chet and Gromov-Hausdorff metrics showed better results than others. The combination of segmentation algorithms $k$-means and threshold optimally suits the segmentation of cytological images.

\section{DISCUSSION}

The analyzed methods of quantitative evaluation of segmentation quality, such as CSP, WSP, PDE, FRAG, AUMA, RUMA provide evaluation for only individual microscopic objects.

To evaluate the quality of segmentation of micro objects' groups, it is necessary to apply metrics. The most common metrics are the classical metrics of Fré chet and Hausdorff. At present, the best known algorithms that implement the Fréchet metric for contours (flat curves) have the computational complexity of $O(m \cdot n)$. Known algorithms for calculating the Hausdorff distance between convex regions (polygons) have the computational complexity of $O(m \cdot n)$. The Hausdorff and Fréchet metrics allow separately measuring the distances between regions and contours of images. To find the shortest distances between regions, the Gromov-Hausdorff metric is used.

The disadvantages of the known algorithms are the following:

1. Algorithms based on the Fré chet metric calculate the distance only between the contours of images;
2. Algorithms based on the Hausdorff metric calculate the distance only between convex regions of images;

3. There are no algorithms that calculate the shortest distance between contours.

The advantages of the developed algorithms are the following:

1. The proposed Gromov-Fréchet metric allows estimating the shortest distance between the contours of images;

2. The use of a combined metric based on the metrics of Gromov-Hausdorff and Gromov-Freche provided the possibility to calculate the shortest distances between contours and non-convex regions of images.

3. The developed EMISQ, which is based on the best known algorithms for calculating the Fréchet and Hausdorff distances, automatically estimates the shortest distances between groups of micro objects.

\section{CONCLUSIONS}

In the article, the authors introduced the GromovFréchet distance and proved that distance is a metric. The method of quantitative evaluation of image segmentation quality is developed, on the basis of which a program module is designed and implemented, which allows calculating the shortest distance between images in an automatic mode.

The scientific novelty of the results is the following:

- for the first time, a Gromov-Fréchet metric was proposed for measuring the shortest distance between the contours of images;

- for the first time, quantitative evaluation method of segmentation quality based on the integrated use of GromovFré chet and Gromov-Hausdorff metrics was applied allowing to evaluate the shortest distances between images.

The practical significance of the results is in the development of software to evaluate the shortest distances between the images. Computer experiments that were conducted on the example of cytological and histological images showed high efficiency of software that was used in image automatic segmentation algorithms.

Table 1 - Comparative analysis of image segmentation

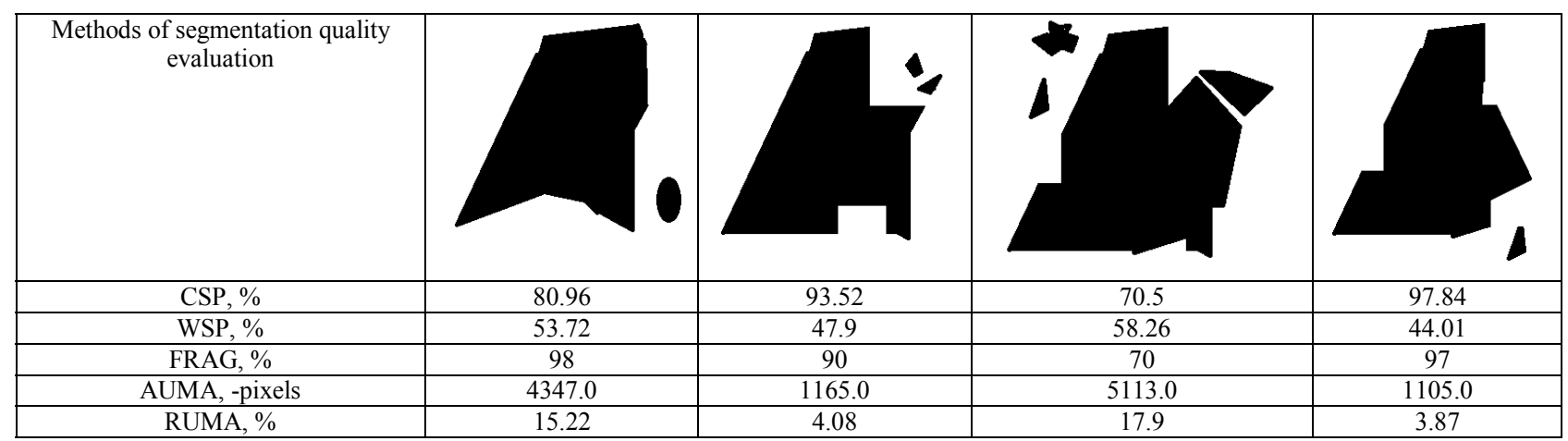

Table 2 - Comparative analysis of image segmentation based on metrics

\begin{tabular}{|l|c|c|c|c|}
\hline Metrics & b) $\rightarrow$ b) & b) $\rightarrow$ c) & b) $\rightarrow$ d) & b) $\rightarrow$ e) \\
\hline Hausdorff & 0 & 19.20 & 21.37 & 46.57 \\
\hline Gromov-Hausdorff & 0 & 19.20 & 21.37 & 46.57 \\
\hline Fréchet & 0 & 36.76 & 26.4 & 52.77 \\
\hline Gromov-Fréchet & 0 & 36.76 & 24.18 & 52.77 \\
\hline Weighted metrics & 0 & 27.98 & 22.78 & 49.67 \\
\hline
\end{tabular}


Further areas of research embrace the development of algorithms of de-paralleling the metric quantitative evaluation method of segmentation quality, which will help speed up the process of segmentation quality evaluation and segmentation algorithm optimization. Besides, a promising area for further investigations is development of a metric for evaluation the similarities of non-convex polygons.

\section{ACKNOWLEDGEMENTS}

The proposed research has been developed within the state budget project "Hybrid Intelligent Information Technology Diagnosing of Precancerous Breast Cancer Based on Image Analysis" (state registration number 1016U002500).

\section{REFERENCES}

1. Yinpeng J. Contrast Enhancement by Multi-scale Adaptive Histogram Equalization / J. Yinpeng, L.Fayadb, A. Laine // Proceedings of SPIE. - 2001. - Vol. 4478. - P. 206-213. DOI: $10.7916 / \mathrm{D} 8 \mathrm{QZ2M} 29$

2. Baron T. H. A Prospective Comparison of Digital Image Analysis and Routine Cytology for the Identification of Malignancy in Biliary Tract Strictures / T. H. Baron, G. Harewood, A. Rumalla // Clinical Gastroenterology and Hepatology. - 2004. - Vol. 2, Issue 3. - P. 214-219. DOI: 10.1016/S1542-3565(04)00006-0

3. Petushi S. Large-scale computations on histology images reveal grade-differentiating parameters for breast cancer / S. Petushi, F. U. Garcia, M. M. Haber // BMC Medical Imaging. - 2006. Vol. 6, Issue 14. - P. 496-499. DOI: 10.1186/1471-2342-6-14

4. Levine M. D. Dynamic measurement of computer generated image segmentations / M. D. Levine, A. Nazif// IEEE Transactions on Pattern Analysis and Machine Intelligence. - 1985. - Vol. 7, Issue 2. - P. 155-164. DOI: 10.1109/TPAMI.1985.4767640

5. Zhang Y. J. A review of recent evaluation methods for image segmentation / Y. J. Zhang // Signal Processing and its Applications (ISSPA) : Sixth International Symposium, Kuala Lumpur Malaysia, Aug 13-16, 2001 : proceedings. - Kuala Lumpur, 2001. - P. 148-151.

6. Berezsky O. Methods of quantitative evaluation of image segmentation quality / O. Berezsky // Signal/Image Processing and Pattern Recognition (UkrOBRAZ'2014) : XIIIth All-Ukraine International Conference, Kyiv, 3-7 November 2014 : proceedings. - Kyiv, 2014. - P. 51-54.

7. Lee S. U. A comparative performance study of several global thresholding techniques for segmentation / S. U. Lee, S. Y. Chung, R. H. Park // Computer Vision, Graphics, and Image Processing. 1990. - Vol. 52, Issue. 2. - P. 171-190.

8. Zhang Y. J. Segmentation evaluation using ultimate measurement accuracy / Y. J. Zhang, J. J. Gerbrands // Image Processing Algorithms and Technique. - 1992. - Vol. 1657. - P. 449-460.

9. Zhang Y. J. Objective and quantitative segmentation evaluation and comparison / Y. J. Zhang, J. J. Gerbrands // Signal Processing. 1994. - Vol. 39, Issue.2. - P. 43-54. DOI:10.1016/01651684(94)90122-8

10. Lopez M. Hausdorff approximation of convex polygons / M. A. Lopez, S. Reisner // Computational Geometry. - 2005. Vol. 32, Issue 2. - P. 139-158. DOI: 10.1016/ j.comgeo.2005.02.002

11. Alt H. Computing the Hausdorff distance between curved objects / H. Alt, L. Scharfz // International Journal of Computational Geometry. - 2008. - Vol. 18. - P. 307-320. DOI: 10.1142/ S0218195908002647

12. Chew L. P. Getting around a lower bound for the minimum Hausdorff distance / L. P. Chew, K. Kedem // Computational
Geometry. - 1998. - Vol. 10, Issue 3. - P. 197-202. DOI: S09257721(97)00032-1

13. Knauer C. Approximate nearest neighbor search under translation invariant hausdorff distance / C. Knauer, M. Scherfenberg // International Journal of Computational Geometry. - 2011. Vol. 21, Issue 3. - P. 369-381. DOI: S0218195911003706

14. Alvarez V. Approximating the minimum weight spanning tree of a set of points in the Hausdorff metric / V. Alvarez, R. Seidel // Computational Geometry. - 2010. - Vol. 43. - P. 94-98.

15. Atallah M. J. Computing Some Distance Functions Between Polygons / M. J. Atallah, C. Celso // Computer Science Technical Reports. - 1990. - Vol. 9. - P. 1-10.

16. Alt H. Computing the Fréchet distance between two polygonal curves / H. Alt, M. Godau // International Journal of Computational Geometry and Applications. - 1995. - Vol. 5. - P. 75-91.

17. Mosig A. Approximately matching polygonal curves with respect to the Fréchet distance / A. Mosig, M. Clausen / Computational Geometry. - 2005. - Vol. 30, Issue 2. - P. 113-127. DOI: 10.1016/ j.comgeo.2004.05.004

18. Buchin K. Computing the Fréchet distance between simple polygons / K. Buchin, M. Buchin, C. Wenk // Computational Geometry. - 2008. - Vol. 441, Issue 1-2. - P. 2-20. DOI: 10.1145/ 1137856.1137870

19. Rote G. Computing the Fr échet distance between piecewise smooth curves / G. Rote // Computational Geometry. - 2007. Vol. 37. - P. 162-174. DOI: 10.1016/j.comgeo.2005.01.004

20. Schlesinger M. I. Frechet Similarity of Closed Polygonal Curves / M. I. Schlesinger, E. V. Vodolazskiy, V. M. Yakovenko // International Journal of Computational Geometry. - 2016. Vol. 26. - P. 53-66. DOI: 10.1142/S0218195916500035

21. Computing the discrete Fréchet distance with imprecise impute / [H.-K. Ahn, C. Knauer, M. Scherfenberg et al.] // International Journal of Computational Geometry. - 2016. - Vol. 22. - P. $27-$ 44. DOI: $10.1142 / \mathrm{S} 0218195912600023$

22. Computing the Fr échet distance between folded polygons / [A. F. Cook, Anne Driemel, Jessica Sherette et al.] // Computational Geometry. - 2015. - Vol. 50. - P. 1-16.

23. Gudmundsson J. Fast algorithms for approximate Fréchet matching queries in geometric trees / J. Gudmundsson, M. Smid // Computational Geometry. - 2015. - Vol. 48. - P. 479-494. DOI:10.1016/j.comgeo.2015.02.003

24. Computing discrete Fréchet distance: Technical Report: CD-TR 94/64 / T. Eiter, H. Mannila // Information Systems Department, Technical University of Vienna. - Vienna, 1994. - 7 p.

25. Deza M. M. Encyclopedia of Distances / M. M. Deza. - Berlin : Springer-Verlag, 2009. $-590 \mathrm{p}$.

26. Gromov M. Metric Structures for Riemannian and NonRiemannian Spaces / M. Gromov. - Boston, MA, Progress in Mathematics, 1999. - $1041 \mathrm{p}$.

27. Regions Matching Algorithms Analysis to Quantify the Image Segmentation Results / [O. Berezsky, Y. Batko, O. Pitsun et al.] // Sensors \& Transducers. - 2017. - Vol. 208, Issue 1. - P. 44-49. DOI: $10.1109 /$ STC-CSIT.2016.7589862

28. Fuzzy system diagnosing of precancerous and cancerous conditions of the breast / [O. Berezsky, S. Verbovyy, L. Dubchak et al.] // Computer Sciences and Information Technologies (CSIT) : XI th International Scientific and Technical Conference, Lviv, 6-10 September 2016 : proceedings. - Lviv, 2016. - P. 200-203. DOI: 10.1109/STC-CSIT.2016.7589906

29.Berezsky O. Automated Processing of Cytological and Histological Images / Oleh Berezsky, Oleh Pitsun // Perspective Technologies and Methods in MEMS Design (MEMSTECH'2016) : XII th International Conference, Lviv-Polyana, 20-24 April 2016 : proceedings. - Lviv, 2016. - P. 51-53. DOI:10.1109/ MEMSTECH.2016.7507518

Article was submitted 14.06.2017. After revision 20.08.2017. 
Березький О. М. ${ }^{1}$, Піцун О. Й. ${ }^{2}$

'Д-р техн. наук, професор, завідувач кафедри комп’ютерної інженерії, Тернопільський національний економічний університет, Тернопіль, Україна

${ }^{2}$ Аспірант, Тернопільський національний економічний університет, Тернопіль, Україна

МЕТОДИ ОЦІКИ ЯКОСТІ СЕГМЕНТАЦІЇ ЗОБРАЖЕНЬ

Актуальність. Розглянуто основні методи кількісної оцінки якості сегментації зображень. Вони використовуються для вибору алгоритмів сегментації для конкретних класів зображень. Об'єктом дослідження $\epsilon$ цитологічні та гістологічні зображення, які використовуються при діагностуванні патологічних процесів в онкології. Предметом дослідження є кількісні методи оцінки якості алгоритмів сегментації.

Мета роботи - введення метрики Громова-Фреше та розроблення метричного методу кількісної оцінки якості сегментації для порівняння алгоритмів сегментації зображень.

Метод. Проаналізовані критерії кількісної оцінки, які базуються на порівнянні та без порівняння з еталонним зображенням. Проаналізовано алгоритми знаходження відстані між зображеннями на основі метрик Фреше, Хаусдорфа, Громова-Хаусдорфа.

Для знаходження відстані між контурами зображень введено відстань Громова-Фреше. Доведено умову тотожності, симетричності та трикутника і показано, що відстань Громова-Фреше $є$ метрикою.

Розроблено метричний метод кількісної оцінки якості сегментації. Він базується на використанні метрик Громова-Хаусдорфа та Громова-Фреше. Метод побудований на основі алгоритмів перетворення неопуклих полігонів у опуклі, алгоритму зважених хорд, алгоритмів обчислення відстаней Фреше та Хаусдорфа. Для знаходження відстані Хаусдорфа між опуклими областями використано алгоритм М. Аталаха. Для знаходження дискретної відстані Фреше використано алгоритм Томаса Ейтера і Хейкі Манілли. Дані алгоритми мають найнижчу обчислювальну складність серед свого класу алгоритмів.

Результати. Введено метрику Громова-Фреше та розроблено метричний метод кількісної оцінки якості сегментації.

Висновки. Проведені експерименти на основі цитологічних зображень підтвердили працездатність програмного забезпечення оцінки відстані між зображеннями. Розроблений метод показав високу точність оцінки відстаней між зображеннями. Розроблений програмний модуль використаний у інтелектуальній системі діагностування передракових і ракових станів молочної залози. Програмне забезпечення може бути використане в різних програмних системах комп’ютерного зору. Перспективними напрямами досліджень $\epsilon$ пошук нових метрик для оцінки відстані між зображеннями.

Ключові слова: сегментація, кількісна оцінка сегментації, метрика Фреше, метрика Хаусдорфа, метрика Громова-Хаусдорфа, метрика Громова-Фреше, полігон, цитологічні зображення

Березский О. Н. ${ }^{1}$, Пицун О. Й. ${ }^{2}$

${ }^{1}$ Д-р техн. наук, профессор, заведующий кафедрой компьютерной инженерии, Тернопольский национальный экономический университет, Тернополь, Украина

${ }^{2}$ Аспирант, Тернопольский национальный экономический университет, Тернополь, Украина

\section{МЕТОДЫ ОЦЕНКИ КАЧЕСТВА СЕГМЕНТАЩИИ ИЗОБРАЖЕНИЙ}

Актуальность. Рассмотрены основные методы количественной оценки качества сегментации изображений. Они используются для выбора алгоритмов сегментации для конкретных классов изображений. Объектом исследования являются цитологические и гистологические изображения, используемые при диагностировании патологических процессов в онкологии. Предметом исследования являются количественные методы оценки качества алгоритмов сегментации.

Цель работы - введение метрики Громова-Фреше и разработка метрического метода количественной оценки качества сегментации для сравнения алгоритмов сегментации изображений.

Метод. Проанализированы критерии количественной оценки, основанные на сравнении и без сравнения с эталонным изображением. Проанализированы алгоритмы нахождения расстояния между изображениями на основе метрик Фреше, Хаусдорфа, ГромоваХаусдорфа.

Для нахождения расстояния между контурами изображений введено расстояние Громова-Фреше. Доказано условие тождественности, симметричности и треугольника и показано, что расстояние Громова-Фреше является метрикой.

Разработан метрический метод количественной оценки качества сегментации. Он базируется на использовании метрик ГромоваХаусдорфа и Громова-Фреше. Метод построен на основе алгоритмов преобразования невыпуклых полигонов в выпуклые, алгоритма взвешенных хорд, алгоритмов вычисления расстояний Фреше и Хаусдорфа. Для нахождения расстояния Хаусдорфа между выпуклыми областями использован алгоритм М. Аталаха. Для нахождения дискретного расстояния Фреше использован алгоритм Томаса Рейтера и Хейкки Маниллы. Данные алгоритмы имеют самую низкую вычислительную сложность среди своего класса алгоритмов.

Результаты. Введено метрику Громова-Фреше и разработано метрический метод количественной оценки качества сегментации.

Выводы. Проведенные эксперименты на основе цитологических изображений подтвердили работоспособность программного обеспечения оценки расстояния между изображениями. Разработанный метод показал высокую точность оценки расстояний между изображениями. Разработанный программный модуль использован в интеллектуальные системе диагностирования предраковых и раковых состояний молочной железы. Программное обеспечение может быть использовано в различных программных системах компьютерного зрения. Перспективными направлениями исследований является поиск новых метрик для оценки расстояния между изображениями.

Ключевые слова: сегментация, количественная оценка сегментации, метрика Громова-Хаусдорфа, метрика Громова-Фреше, полигон, цитологические изображения.

\section{REFERENCES}

1. Yinpeng J., Fayadb L., Laine A. Contrast Enhancement by Multiscale Adaptive Histogram Equalization, Proceedings of SPIE, 2001, Vol. 4478, pp. 206-213. DOI: 10.7916/D8QZ2M29

2. Baron T. H., Harewood G., Rumalla A. A Prospective Comparison of Digital Image Analysis and Routine Cytology for the
Identification of Malignancy in Biliary Tract Strictures, Clinical Gastroenterology and Hepatology, 2004, Vol. 2, Issue 3, pp. 214-219. DOI: $10.1016 / \mathrm{S} 1542-3565(04) 00006-0$

3. Petushi S., Garcia F. U., Haber M. M. Large-scale computations on histology images reveal grade-differentiating parameters for breast cancer, BMC Medical Imaging, 2006, Vol. 6, Issue 14, pp. 496-499. DOI: 10.1186/1471-2342-6-14 
4. Levine M. D., Nazif A. Dynamic measurement of computer generated image segmentations, IEEE Transactions on Pattern Analysis and Machine Intelligence, 1985, Vol. 7, Issue 2, pp. 155-164. DOI: 10.1109/TPAMI.1985.4767640

5. Zhang Y. J. A review of recent evaluation methods for image segmentation, Signal Processing and its Applications (ISSPA), Sixth International Symposium, Kuala Lumpur Malaysia, Aug 13-16, 2001, proceedings. Kuala Lumpur, 2001, pp. 148-151.

6. Berezsky O. Methods of quantitative evaluation of image segmentation quality, Signal/Image Processing and Pattern Recognition (UkrOBRAZ'2014) : XIIIth All-Ukraine International Conference, Kyiv, 3-7 November 2014: proceedings. Kyiv, 2014, pp. 51-54.

7. Lee S. U., Chung S. Y., Park R. H. A comparative performance study of several global thresholding techniques for segmentation, Computer Vision, Graphics, and Image Processing,1990, Vol. 52, Issue. 2, pp. 171-190.

8. Zhang Y. J., Gerbrands J. J. Segmentation evaluation using ultimate measurement accuracy, Image Processing Algorithms and Technique, 1992, Vol. 1657, pp. 449-460.

9. Zhang Y. J., Gerbrands J. J. Objective and quantitative segmentation evaluation and comparison Signal Processing, 1994, Vol. 39, Issue.2, pp. 43-54. DOI:10.1016/0165-1684(94)90122-8

10. Lopez M. A., Reisner S. Hausdorff approximation of convex polygons, Computational Geometry, 2005, Vol. 32, Issue 2, pp. $139-158$. DOI: $10.1016 /$ j.comgeo.2005.02.002

11. Alt H., Scharfz L. Computing the Hausdorff distance between curved objects, International Journal of Computational Geometry, 2008, Vol. 18, pp. 307-320. DOI: 10.1142/S0218195908002647

12. Chew L. P., Kedem K. Getting around a lower bound for the minimum Hausdorff distance, Computational Geometry, 1998, Vol. 10, Issue 3, pp. 197-202. DOI: S0925-7721(97)00032-1

13. Knauer C., Scherfenberg M. Approximate nearest neighbor search under translation invariant hausdorff distance, International Journal of Computational Geometry, 2011, Vol. 21, Issue 3, pp. 369-381. DOI: S0218195911003706

14. Alvarez V., Seidel R. Approximating the minimum weight spanning tree of a set of points in the Hausdorff metric, Computational Geometry, 2010, Vol. 43, pp. 94-98.

15. Atallah M. J., Celso C. Computing Some Distance Functions Between Polygons, Computer Science Technical Reports, 1990, Vol. 9, pp. 1-10.

16. Alt H., Godau M. Computing the Fréchet distance between two polygonal curves, International Journal of Computational Geometry and Applications, 1995,Vol. 5, pp. 75-91.
17. Mosig A., Clausen M. Approximately matching polygonal curves with respect to the Fréchet distance, Computational Geometry, 2005, Vol. 30, Issue 2, pp. 113-127. DOI: 10.1016/ j.comgeo.2004.05.004

18. Buchin K., Buchin M., Wenk C. Computing the Frŭchet distance between simple polygons, Computational Geometry, 2008, Vol. 441, Issue 1-2, pp. 2-20. DOI: 10.1145/1137856.1137870

19. Rote G. Computing the Fré chet distance between piecewise smooth curves, Computational Geometry, 2007, Vol. 37, pp. 162-174. DOI: 10.1016/j.comgeo.2005.01.004

20. Schlesinger M. I., Vodolazskiy E. V., Yakovenko V. M. Frechet Similarity of Closed Polygonal Curves, International Journal of Computational Geometry, 2016, Vol. 26, pp. 53-66. DOI: $10.1142 / \mathrm{S} 0218195916500035$

21. Ahn H.-K., Knauer C., Scherfenberg M. et al. Computing the discrete Fr échet distance with imprecise impute, International Journal of Computational Geometry, 2016, Vol. 22, pp. 27-44. DOI: $10.1142 / \mathrm{S} 0218195912600023$

22. Cook A. F., Driemel Anne, Sherette Jessica et al. Computing the Fréchet distance between folded polygons, Computational Geometry, 2015, Vol. 50, pp. 1-16.

23. Gudmundsson J., Smid M. Fast algorithms for approximate Fréchet matching queries in geometric trees, Computational Geometry, 2015, Vol. 48, pp. 479-494. DOI:10.1016/ j.comgeo.2015.02.003

24. Eiter T., Mannila H. Computing discrete Fréchet distance: Technical Report: CD-TR 94/64 / Information Systems Department, Technical University of Vienna. Vienna, 1994, 7 p.

25. Deza M. M. Encyclopedia of Distances. Berlin, Springer-Verlag, 2009, $590 \mathrm{p}$.

26. Gromov M. Metric Structures for Riemannian and NonRiemannian Spaces. Boston, MA, Progress in Mathematics, 1999, $1041 \mathrm{p}$.

27. Berezsky O., Batko Y., Pitsun O. et al. Regions Matching Algorithms Analysis to Quantify the Image Segmentation Results, Sensors \& Transducers, 2017, Vol. 208, Issue 1, pp. 44-49. DOI: 10.1109/STC-CSIT.2016.7589862

28. Berezsky O., Verbovyy S., Dubchak L. et al. Fuzzy system diagnosing of precancerous and cancerous conditions of the breast, Computer Sciences and Information Technologies (CSIT) : XI th International Scientific and Technical Conference, Lviv, 6-10 September 2016 : proceedings. Lviv, 2016, pp. 200-203. DOI: $10.1109 /$ STC-CSIT.2016.7589906

29. Berezsky O., Pitsun O. Automated Processing of Cytological and Histological Images, Perspective Technologies and Methods in MEMS Design (MEMSTECH'2016) : XII th International Conference, Lviv-Polyana, 20-24 April 2016 : proceedings. Lviv, 2016, pp. 51-53. DOI: 10.1109/MEMSTECH.2016.7507518 